\section{EVOLUÇÃO QUÍMICA E ENSINO DA QUÍMICA}

Hernâni Maia

J.J. Moura Ramos
A forte componente cultural da temática ligada à Evolução Química e à Origem da Vida torna este domínio científico extremamente fascinante para estudantes e professores, tanto ao nível do ensino secundário como do ensino superior. Este facto, associado à interdisciplinaridade obrigatória do estudo da Evolução Química, dão a este domínio da ciência características únicas que poderiam fazer dele um tema privilegiado no contexto do ensino das ciências, tanto nos ramos científicos como também nos ramos não científicos.

Existem várias tentativas, realizadas em diferentes países, para introduzir os temas e os conceitos da Evolução Química no contexto da educação em Química. Foi com o objectivo de tomar contacto com essas experiências e conhecer os seus sucessos e limitaçðes que pedimos a colaboração de duas pessoas, das mais activas neste domínio, no sentido de nos transmitirem as suas opinioes e experiências àcerca deste problema. Sugerimos dois temas de desenvolvimento:

1) a Evolução Química como tema unificador no ensino das ciências;

2) a Origem da vida (ou mais geralmente a Evolução Química) como tema curricular no Ensino da Química. Porquê? A que níveis?

A resposta foi pronta e entusiasta pelo que agradecemos aos Professores Clifford Matthews, da Universidade de Illinois e, Wolfram Thiemann, da Universidade de Bremen, a valiosa colaboração que prestaram a este Boletim.

\section{A EVOLUÇÃO UNIVERSAL: UM TEMA UNIFICADOR PARA O ENSINO DA CIÊNCIA}

Clifford Matthews $\left({ }^{*}\right)$
$\mathrm{Na}$ nossa época - que podemos caracterizar como um período de transição para uma civilização tecnológica humanizada - o cidadão culto sente mais do que nunca a necessidade de adquirir uma formação científica, deseja cada vez mais estar ao corrente do que melhor se publica no contexto do moderno jornalismo científico para poder responder adequadamente às modificaçб̃es de uma sociedade predominantemente moldada pela ciência. Satisfazer esta necessidade é o maior desafio que actualmente se coloca aos professores de ciências. Temos que encontrar formas para possibilitar aos estudantes das ciências humanas e das profissð̋es não cientficas o estabelecimento de uma relação pessoal com a ciência, encarada simultaneamente como actividade utilitária essencial e como forma de realização e expansão do espírito humano.

$\mathrm{Na}$ sequência do desenvolvimento científico que ocorreu depois da II Guerra Mundial foram criados nos Estados Unidos cursos de ciências naturais obrigatórios para estudantes de disciplinas não científicas que passaram a ser incluídos entre as exigências para a admissão nas universidades e nos cursos superiores. Estas experiências não parecem ter sido muito profícuas tanto para os professores como para os alunos. O que se oferecia nestes cursos eram frequentemente versðes desenxabidas dos currícula correntes nos primeiros anos dos cursos de ciências, em que se procurava mais a extensão que a profundidade, resultando a banalidade e a superficialidade com pequeno conteúdo objectivo. Esta experiência de um modo geral negativa sugere que, para levar a ciência aos estudantes e os estudantes à ciência, os cursos deverão ser completamente reformulados, tendo que ser inevitavelmente construídos à volta de um núcleo fundamental de conhecimentos científicos e dados de um modo completamente diferente do usual.

Para que estes cursos sejam eficazes - e mesmo atraentes - penso terem que ser observados novos princípios para a sua elaboração:

1. Um tema unificador de interesse reconhecido pode aumentar fortemente os atractivos deste tipo de curso.

2. Uma forte componente cultural - histórica, bio-

(*) Department of Chemistry, University of Illinois at Chicago, P.O. Box 4348, Chicago, Illinois 60680, EUA. 
gráfica, sociológica, filosófica, tecnológica e ética deveria emergir naturalmente das actividades científicas essenciais.

3. Apesar da grande importância do cálculo em ciência, a matemática não deve constituir necessariamente a linguagem simbólica preferida para a transmissão dos conceitos.

4. A experiência laboratorial em sentido restrito deveria ser evitada e substituída por actividades experimentais cuidadosamente escolhidas de forma a reforçar a estrutura global do curso.

Estes princípios foram utilizados na Universidade de Illinois em Chicago para conceber um curso curto mas condensado, destinado a estudantes de ramos não científicos. Este curso é baseado na mais profunda conquista da ciência moderna, a saber, o desenvolvimento de uma visão universal da evolução na qual a química é encarada como disciplina central que estabelece a ligação entre a astronomia, a geologia e a biologia. Com Teilhard de Chardin sabemos hoje que «o homem só pode ser compreendido ascendendo a partir da física, da química, da biologia e da geologia... o homem é evolução tornada consciente de si própria».
O curso Química e Vida começa assim com uma abordagem interdisciplinar da evolução - química, biológica, cultural - que conduz directamente a uma discussão sobre a origem da vida. Foi em 1953, ano em que se assistiu ao esclarecimento da estrutura das proteínas e da famosa dupla hélice do ADN, que a experiência de Miller-Urey repôs na ordem do dia a origem da vida como tema científico e o tornou um dos mais fascinantes e fecundos domínios da investigação actual. Segue-se uma panorâmica sobre as modernas concepçðes àcerca da natureza dos átomos, das moléculas e das macromoléculas informativas. Isto constitui o núcleo técnico do curso em que o simbolismo da química estrutural é sublinhado preferencialmente ao da matemática, acentuando-se o significado da arquitectura molecular no contexto do mundo evolutivo que nos rodeia, em particular do mundo orgânico no seu cenário inorgânico. O curso termina com uma discussão simples e sistemática sobre a vida (a capacidade para utilizar a energia para criar ordem), o homem (quinta-essência da nébula solar?) e a ciência (uma sonda permanente no mistério da ordem). $\mathrm{Na}$ tabela 1 apresenta-se com maior pormenor a estru-

TABELA 1 - Esboço do curso Química e Vida

\begin{tabular}{|c|c|c|c|}
\hline $\begin{array}{c}\text { Semana } \\
1\end{array}$ & $\begin{array}{l}\text { Aula de exposição } \\
\text { A Exploração Cientifica } \\
\text { Newton, Pasteur, Darwin } \\
\text { Unidade da bioquimica } \\
\text { Unidade da cosmoquimica }\end{array}$ & $\begin{array}{l}\qquad \text { Filme } \\
\text { Abertura } \\
\text { História da Astrologia }\end{array}$ & $\begin{array}{l}\text { Discussão de laboratório } \\
\text { Surpresa face às coisas: } \\
\text { acontecimentos quimicos }\end{array}$ \\
\hline 2 & $\begin{array}{l}\text { A Biosfera Evolutiva } \\
\text { A experiência de Miller-Urey: Origem da vida } \\
\text { O efeito da estufa: o écran de ozono } \\
\text { Atmosferas planetárias }\end{array}$ & $\begin{array}{l}\text { Universo } \\
\text { Potências de dez }\end{array}$ & $\begin{array}{l}\text { Produtos naturais: } \\
\text { a cafeina do chá }\end{array}$ \\
\hline 3 & $\begin{array}{l}\text { A Natureza da Matéria } \\
\text { Elementos: a tabela periódica } \\
\text { atomos: electrðes, protðes, neutrōes }\end{array}$ & A Tabela Periódica & $\begin{array}{l}\text { Energia e matéria: } \\
\text { os aspectos atómicos }\end{array}$ \\
\hline 4 & $\begin{array}{l}\text { Ligações Químicas } \\
\text { Compostos iónicos e covalentes } \\
\text { Orbitais e ligação } \\
\text { Complementaridade: ondas e partículas }\end{array}$ & Átomo de Hidrogénio & $\begin{array}{l}\text { Estrutura atómica: } \\
\text { o modelo de } \\
\text { Rutherford-Bohr } \\
\end{array}$ \\
\hline 5 & $\begin{array}{l}\text { Os Compostos Orgânicos } \\
\text { Carbono: estruturas e Kekulé } \\
\text { Encadeamento, homologia, isomerismo } \\
\text { Hidrocarbonetos: petróleo, combustíveis fósseis }\end{array}$ & Catálise & $\begin{array}{l}\text { Arquitectura molecular: } \\
\text { o jogo de Kekulé }\end{array}$ \\
\hline 6 & $\begin{array}{l}\text { A Síntese Orgânica } \\
\text { Grupos funcionais: reactividade } \\
\text { Polimeros: naturais e sintéticos } \\
\text { Esteroides: unidade e diversidade }\end{array}$ & A Origem da Vida & $\begin{array}{l}\text { Produtos sintéticos: } \\
\text { aspirina } 100 \% \text { pura }\end{array}$ \\
\hline 7 & $\begin{array}{l}\text { A Proteínas } \\
\text { Estrutura: niveis } 1,2,3,4 \\
\text { Mioglibina e hemoglibina } \\
\text { Actividade: enzimas, estereoespecificidade }\end{array}$ & A Mioglobina & $\begin{array}{l}\text { Polímeros sintéticos: } \\
\text { o truque da corda } \\
\text { de nylon }\end{array}$ \\
\hline 8 & $\begin{array}{l}\text { Os Ácidos Nucleicos } \\
\text { Estrutura: a dupla hélice } \\
\text { Réplica: genes, mutação } \\
\text { Informação: o código genético }\end{array}$ & ADN: o plano da vida & $\begin{array}{l}\text { Seminário de investigação: } \\
\text { a origem das proteínas }\end{array}$ \\
\hline 9 & $\begin{array}{c}\text { A Expressão da Hereditariedade } \\
\text { ADN } \rightarrow \text { ARN } \rightarrow \text { proteínas } \\
\text { Virus, ADN recombinante } \\
\text { Engenharia genética }\end{array}$ & A Química da Célula & $\begin{array}{l}\text { Separação dos produtos } \\
\text { cromotografia } \\
\text { dos aminoácidos }\end{array}$ \\
\hline 10 & $\begin{array}{l}\text { Flechas do Tempo e Evolução } \\
\text { Entropia: sistemas reversiveis } \\
\text { Sintropia: sistemas irreversiveis } \\
\text { O Universo Inesperado }\end{array}$ & $\begin{array}{l}\text { Manual do Universo } \\
\text { Porque Cria o Homem }\end{array}$ & $\begin{array}{l}\text { Criatividade: } \\
\text { projectos } \\
\text { dos estudantes }\end{array}$ \\
\hline
\end{tabular}


tura deste curso. Na medida em que estimular o pensamento criativo é um dos nossos objectivos, procuramos explicitar a importância de algumas dualidades e complementaridades que emergem naturalmente das descobertas científicas. Por exemplo, os conceitos de continuidade e descontinuidade, de simetria e de assimetria e de ordem e desordem (ver tabela 2). Do ponto de vista metodológico, os modos de descoberta como a integração e a redução, a intuição e a análise são também considerados assim como os aspectos contraditórios da tecnologia que continuamente se nos deparam: os da ameaça e da esperança.

TABELA 2 - Relaçðes binárias em ciência

\begin{tabular}{|c|c|c|}
\hline Categoria & \multicolumn{2}{|c|}{ Relações binárias } \\
\hline \multirow{3}{*}{$\begin{array}{c}\text { Conceitos } \\
\text { da } \\
\text { ciência }\end{array}$} & $\begin{array}{c}\text { Continuidade } \\
\text { onda }\end{array}$ & $\begin{array}{l}\text { Descontinuidade } \\
\text { particula }\end{array}$ \\
\hline & $\begin{array}{c}\text { Simetria } \\
\text { quimica do silício }\end{array}$ & $\begin{array}{c}\text { Assimetria } \\
\text { química do carbono }\end{array}$ \\
\hline & $\begin{array}{l}\text { Ordem } \\
\text { evolução }\end{array}$ & $\begin{array}{l}\text { Desordem } \\
\text { entropia }\end{array}$ \\
\hline $\begin{array}{c}\text { Métodos } \\
\text { da } \\
\text { ciência }\end{array}$ & Integraçãoo & Redução \\
\hline $\begin{array}{c}\text { Abordagem } \\
\text { da } \\
\text { ciência }\end{array}$ & Intuição & Análise \\
\hline $\begin{array}{c}\text { Aplicaçð̄es } \\
\text { da } \\
\text { ciência }\end{array}$ & Ameaça & Esperança \\
\hline
\end{tabular}

Química e Vida é um curso de dez semanas constituído por duas aulas sernanais de noventa minutos apoiadas com filmes e diapositivos cuidadosamente escolhidos e reforçadas com três horas semanais de discussão de laboratório orientadas por assistentes preparados para o efeito. Não foi encontrado nenhum livro de texto particularmente apropriado para a nossa abordagem interdisciplinar. Para suprir esta lacuna, distribuem-se todas as semanas, nas aulas teóricas e nas discussões de laboratório, apontamentos policopiados. Para além disso, o livro de Robert Jastrow Red Giants and White Dwarfs(1) (segunda edição) tem sido muito útil como leitura prévia, como formação básica necessária para a frequência do curso. Cada discussão de laboratório inclui uma breve síntese do tema abordado na semana anterior, a seguir à qual os estudantes são submetidos a pequenos questionários escritos cujo objectivo é o de auxiliar os estudantes a assimilar as novas ideias adquiridas. Os resultados destes questionários servem, conjuntamente com os exames, intermédio e final, para avaliar o nível atingido por cada estudante. Em cada trimestre matriculam-se cerca de trezentos estudantes não licenciados, alguns tendo acabado recentemente o ensino secundário, outros já próximos de terminar a licenciatura universitária. Não havendo exigências prévias para a matrícula, os alunos diferem bastante nas suas capacidades e maturidade. Esta situação é certamente um desafio à elaboração de um curso que tenha significado a vários níveis de sofisticação. Cada estudante dá, na fase final, uma contribuição pessoal através da apresentação de um trabalho original - um ensaio ou um poema, um trabalho gráfico ou uma sugestão pedagógica, etc. ... - que pode ser incorporada nas aulas futuras deste curso em permanente reformulação e com uma importante componente visual.

A resposta dos alunos ao curso Química e Vida tem sido até agora extremamente entusiástica. Parece ter-se conseguido transmitir algo de fascínio e de visão da ciência como actividade cultural, de tal forma que os estudantes encaram a temática do curso na sua relação com a história, a linguagem, a arquitectura. Parece assim conseguir-se fornecer à imaginação algo que seria difícil por outros meios. Os alunos deixam de ter temor ou indiferença perante a ciência e adquirem indubitavelmente uma atitude mais apta para encarar os problemas resultantes da aplicação generalizada da ciência na nossa sociedade.

A partir da nossa experiência como docentes ocorre-nos perguntar: Existirá um tema mais apropriado do que a evolução universal para acrescentar profundidade e perspectiva aos programas especializados exigidos aos estudantes (licenciados e não licenciados) de ciências? Os estudantes universitários de química e bioquímica receberam muito positivamente um curso mais avançado sobre evolução química, $D a$ Via Láctea ao $A D N$, que contou com a participação de professores de outros departamentos científicos convidados para o efeito, assim como um curso de Química do Ambiente em que se sublinhava o papel da evolução no desenvolvimento da biosfera. Podemos afirmar na generalidade que o estímulo produzido pela introdução do pensamento evolucionista nestes cursos assim como em todos os seminários interdisciplinares universitários sobre temas como $O$ Tempo, A Simetria na Arte e na Ciência, O que é a Verdade?, Paradigma e Paradoxo e outros tópicos de natureza filosófica, sugere que os cursos de química geral do primeiro ano universitário devem ser enriquecidos pela introdução da problemática evolucionista que explicita e sublinha a unidade e universalidade da ciência.

(1) Editado por Harper and Row, Nova York. A edição francesa (Editions du Seuil, Collection Points-Sciences, Paris) tem o título: Des astres, de la vie et des hommes.

\section{EQUILÍBRIO QUÍMICO E CINÉTICA QUÍMICA}

\author{
Ana M. Simões \\ Raquel M. Gonçalves
}

\section{Uma edição da \\ Sociedade Portuguesa de Química}

